\title{
TA'ARUF LOKALITAS: \\ INTEGRASI HUKUM ISLAM DAN HUKUM ADAT \\ TERHADAP FENOMENA GREDOAN DI SUKU \\ USING BANYUWANGI
}

\author{
Qurrotul Ainiyah \\ Institut Agama Islam Al Falah As Suniyyah Kencong Jember, Indonesia \\ jayaaini@gmail.com
}

\begin{abstract}
This research is a study which used a qualitative approach with the type field research, which is related to the Gredoan tradition as the event of looking for a life partner in using community located on Macan Putih Village, Kabat district in banyuwangi. In this paper will explain how is the custom to find a mate in Banyuwangi society that has lasted since long ago. Gredoan is the relations between customary law and Islamic law which seeks to integrate between the customary laws with Islamic law in matters of marriage. the Contributions of research are: First, there is public space in the form of practice the ta'aruf process towards marriage in Banyuwangi Using society which known as gredoan custom. Second, that Islamic law turns out to have spaces to accommodate the customs as the joints of Islamic law. gredoan Tradition as an al-'urf in using community of banyuwangi in ta'aruf process towards marriage, it obtains legitimacy by the maqāșid al-syarī‘ah which is based on the rules is al-'âdat al-Muhakkamah.
\end{abstract}

Keywords: Islamic Law, Customary Law, Gredoan

Abstrak. Penelitian ini adalah kajian yang menggunakan pendekatan kualitatif dengan jenis penelitian lapangan (field research), yang berkaitan dengan tradisi Gredoan sebagai proses ajang mencari pasangan hidup dimasyarakat suku using yang terdapat didesa macan putih kecamatan kabat. Dalam paper ini akan dipaparkan bagaimana adat mencari jodoh dimasyarakat banyuwangi yang telah berlangsung sejak dahulu. Gredoan adalah bentuk relasi antara hukum adat dan hukum islam yang berusaha mengintegrasikan antara hukum adat dengan hukum islam dalam hal perkawinan. Kontribusi penelitian yaitu: Pertama, adanya ruang publik berupa praktek proses ta'aruf menuju pernikahan dimasyarakat using banyuwangi yang dikenal dengan adat gredoan. Kedua, bahwa hukum Islam ternyata mempunyai ruang-ruang untuk menampung adatistiadat sebagai sendi-sendi hukum Islam. Tradisi Gredoan sebagai al-'Urf dimasyarakat using banyuwangi dalam proses ta'aruf menuju pernikahan, mendapatkan legitimasi dengan adanya tinjauan Maqasid Syari'ah yang di landasi dengan kaidah "al-'adat alMuhakkamah".

Kata Kunci: Hukum Islam, Hukum Adat, Gredoan 


\section{Pendahuluan}

Indonesia mempunyai ragam adat budaya dan hukum adatnya, keberagaman adat budaya dan hukum adatnya di indonesia dikarnakan sejarah perkembangan budayanya dari zaman melayu polonesia dengan pergaulan hidup, tempat kediaman dan lingkungan alamnya berbeda. Dalam kehidupan masyarakat Indonesia yang juga dipengaruhi tradisi agama baik Hindu, Islam, dan Kristen. Dengan lahirnya Rebuplik Indonesia terwujudlah cita dari berbagai masyarakat adat yang berbeda-beda, sehingga menjadi "Bhinaeka Tunggal Ika" walupun berbeda-beda menjadi satu kesatuan dalam wadah Negara Pancasila. ${ }^{1}$

Keberagaman adat itu juga berimplikasi pada tata cara perkawinan dalam hukum adat masyarakat Indonesia, misalnya tradisi merari suku sasak di Lombok, tradisi ngunduh mantu, tradisi Kawin colongan di banyuwangi dan lain sebagainya. Ada pula beberapa tradisi budaya yang mengatur proses sebelum perkawinan sebut saja salah satunya gredoan yang merupakan tradisi acara ajang pencari jodoh didaerah using banyuwangi.

Sedangkan dalam Islam memiliki etika dalam pergaulan dan mengadakan perkenalan antara pria dan wanita sebelum menuju jenjang pernikahan. Yaitu suatu proses yang dikenal dengan istilah ta'aruf atau perkenalan. Ta'aruf dalam islam yaitu proses untuk dapat mengenal kepribadian, latar belakang sosial, budaya, pendidikan, keluarga, maupun agama kedua belah pihak. Dengan tetap menjaga martabat sebagai manusia yang dimuliakan Allah, artinya tidak terjerumus pada perilaku tidak

\footnotetext{
1 Hilman Hadikususma, Hukum Perkawinan Adat, (Bandung: Citra Aditya Bakti,1999) 12.

2 Tihami, Fikih Munakahat, ( Jakarta : PT RajaGrafindo Persada 2010) 23.
}

senonoh, maka bisa diteruskan dengan saling mengenal kondisi keluarga masing-masing, misalnya dengan jalan silaturrahmi ke orang tua keduanya. ${ }^{2}$

Ta'aruf dengan jalan silaturrahmi ini dilakukan untuk bahan pertimbangan bagi yang bersangkutan sebelum memutuskan untuk hidup bersama. Untuk keperluan tersebut agama Islam memberikan kesempatan melihat dan mengenali calon. ${ }^{3}$ Dengan memberi batasan-batasan dalam pergaulan antara laki-laki dengan perempuan. Misalnya, larangan untuk mendekati zina. ${ }^{4}$ Ada beberapa macam proses ta'aruf yang biasa jumpai dalam 'urf di Masyarakat: Pertama, mencari jodoh sendiri, Kedua, dijodohkan oleh keluarga baik semasa kecil atau sudah besar, Ketiga, langsung dipinang dari salah satu pihak calon mempelai, keempat ; perjodohan lewat perantara, seperti lewat pihak ketiga yang dipercayainya seperti halnya biro jodoh. Dan beberapa daerah di Indonesia mempunyai tradisi unik dalam hal mencari jodoh atau perjodohan. Salah satunya yang ada pada masyarakat using Banyuwangi, proses pencarian jodoh atau perjodohan dilakukan dengan sebuah tradisi yaitu; tradisi Gredoan, Bathokan, dan Mlayokaken. Namun diantara ketiga tradisi tersebut yang masih tetap terjaga dan dilestarikan hingga saat ini adalah tradisi Gredoan. ${ }^{5}$

Gredoan merupakan adat ajang pencarian jodoh Desa Macan Putih Kecamatan Kabat Kabupaten Banyuwangi, Gredoan dilaksanakan setiap tahun bersamaan dengan peringatan perayaan Maulid Nabi Muhammad SAW yang selalu diadakan secara besar-besaran dan merupakan

3 Rahmat Hakim, Hukum Perkawinan Islam (Bandung : CV Pustaka Setia, 2000), 44.

4 Tihami, Fikih Munakahat, 22.

5 Sheila Nurvatisna, "Tradisi Gredoan", http://osingkertajasa.wordpress.com $(15$ Desember 2015). 
perayaan Maulid terbesar di wilayah kabupaten Banyuwangi. ${ }^{6}$ Masyarakat using banyuwangi mempunyai kepercayaan bahwa di bulan Maulid Nabi ini adalah bulan yang baik untuk mencari jodoh dan melakukan pernikahan bagi pasangan muda-mudi yang telah cukup umurnya. Sebab melakukan pernikahan bagi muda-mudi yang telah cukup umur dan sudah siap untuk menuju jenjang pernikahan juga dianggap telah mengikuti sunnah Nabi. ${ }^{7}$

Tulisan ini bermaksud mengeksplorasi tentang konsep ta'aruf lokalitas dalam pandangan hukum adat dan hukum Islam dengan mengangkat fenomena budaya suku using banyuwangi berupa tradisi Gredoan.

Pertanyaan-pertanyaan yang hendak dijawab dalam tulisan ini adalah; bagaimana praktek proses ta'aruf dalam tradisi Gredoan di masyarakat using Kecamatan Kabat Kabupaten Banyuwangi? bagaimana mengintegrasikan antara hukum islam dengan hukum adat yang terjadi dalam tradisi Gredoan ini?

Untuk menjawab pertanyaan tersebut, bagian selanjutnya dari tulisan ini adalah; pada pembahasan pertama akan berusaha mengkaji wacana tentang ta'aruf sebagai tradisi menuju perkawinan. Bagian kedua akan membahas Gredoan sebagai tradisi lokal masyarakat using banyuwangi dan Terakhir, tulisan ini akan ditutup dengan diskusi tentang integrasi hukum islam dengan hukum adat dalam tradisi gredoan.

6 Dwi Pranoto, Membicarakan Seni Dan Sastra Banyuwangi (Bali : Pustaka Larasan, 2014), 77.

${ }^{7}$ Pranoto, Membicarakan Seni, 77.

8 Amir Syarifuddi, Ushul Fiqh, Jilild 2 (Jakarta: Logos wacana ilmu 2001) 363

9 Satria Effendi, Ushul Fiqh (Jakarta : Kencana, 2009), 153.

\section{Ta'aruf sebagai 'Urf Menuju Perkawinan}

Kata al-'Urf berasal dari kata 'arafa, yang mempunyai derivasi kata "al-ma'ruf" yang berarti sesuatu yang dikenal atau diketahui. ${ }^{8}$ Secara etimologi berarti sesuatu yang dipandang baik dan diterima oleh akal sehat. ${ }^{9}$

Secara harfiyah, al-'Urf adalah suatu keadaan, ucapan, perbuatan, atau ketentuan yang telah dikenal manusia dan telah menjadi tradisi untuk melaksanakan atau meninggalkannya.

Di kalangan masyarakat, al-'Urf ini sering disebut sebagai adat ${ }^{10}$ dengan kata lain al-'Urf dengan adat itu tidak ada perbedaan. Diantara keduanya tidak mengandung perbedaan signifikasi adat dan al-'Urf secara terminologis tidak memiliki perbedaan prinsipil.11

Misalnya dalam kitab fiqh terdapat ungkapan hadhâ thabit bi al'urf wa al-'adah (ketentuan itu berdasarkan al-'Urf dan al-'adât), maka makna yang dimaksud keduanya adalah sama. Penyebutan al-adat setelah kata al-'Urf berfungsi sebagai penguat (ta'kid) saja, bukan kalimat tersendiri yang mengandung makna berbeda $(\text { ta'sis })^{12}$

Secara Umum al-'Urf diamalkan oleh semua ulama fiqh terutama dari kalangan Madzhab Hanafiyyah dan Malikiyyah. Ulama' Hanafiyyah menggunakan istihsan (salah satu metode ijtihad yang mengambil sesuatu yang lebih baik yang tidak diatur oleh syara') dalam berijtihad, dan salah satu istihsan adalan istihsan al-'urf didahulukan atas qiyas khafi (qiyas yang ringan) dan juga didahulukan atas nash

10 Rahcmat Syafe'i, Ilmu Ushul Fiqh (Bandung : CV Pustaka Setia, 2007), 128.

${ }^{11}$ Abdul Wahhab Khallaf, Ilm Ushul Fiqh, (Qahirah: Dar al-Qalam, tt) 89

12 Abdul Karim Zaidan, al- Wajiz Fi Ushul al-Fiqh, (kairo: Dhar al-Fikr,tt) 155 
yang umum, dalam arti al-'Urf mentakhshis nash yang umum.

Malikiyyah menjadikan al-'Urf dalam bentuk-bentuk muamalah (hubungan kepentingan) yang telah menjadi adat kebiasaan dan telah berlangsung ajeg (konstan) di tengah masyarakat madinah.

Ulama' Syafi'iyyah banyak menggunakan al-'Urf dalam hal-hal yang tidak menemukan ketentuan batasan dalam syara' maupun penggunaan bahasa. Dalam menanggapi adanya penggunaan al-'Urf dalam fiqh, alsuyuthi mengulasnya dengan mengembalikannya kepada kaidah al'adat muhakkamah.

Posisi al-'Urf (custom, tradition, conventional rule of community) ini tingkat pentingnya bukan hanya dalam pelaksanaan hokum islam saja tetapi semua system hukum yang ada di dunia ini terbangun, tertetapkan dan tersistematisir menurut ligika hukum sedikit banyak senantiasa mempertimbangkan al-'Urf merupakan unsur universal dan esensial dalam setiap pembangunan hukum.

Secara garis besar al-'Urf dibagi menjadi dua bagian pertama al-Urf shahih yaitu kebiasaan yang dikenal oleh umat manusia dan tidak berlawanan dengan hukum syara'. Kedua al-'Urffasid sebuah kebiasaan yang dikenal oleh manusia dan berlawanan dengan hukum syara'13 makna dari pembagian ini menurut para ulama' adalah bahwa adat kebiasaan dan al-'Urf itu bisa dijadikan sebuah sandaran untuk menetapkan hukum syar'i apabila tidak terdapat nash syar'i atau lafad sharih (tegas) yang bertentangan dengannya.

Penggunaan 'Urf dalam fiqh, AlSuyuthi mengulasnya dengan mengembalikannya kepada kaidah: al'adât muhakamah "Adat atau tradisi

${ }^{13}$ Abdul Wahhab, Ilm Ushul Fiqh, 88 (yang baik) dapat dijadikan acuan hukum". Kaidah tentang adat ini merupakan sumber hukum Islam yang aspiratif, akomodatif dan fleksibel.

Tradisi suatu masyarakat dapat berkembang, berbeda, dan berubah sesuai dengan peningkatan ekonomi, sosial, pendidikan dan politik warganya. Perubahan semacam ini membuat hukum harus pro aktif mengawalnya, sehingga tidak out of date.

Kaidah ini dalam rangka menghantarkan substansi aplikasi hukum Islam yang harus membawa misi yaitu menciptakan mashalihu al-ibad (kemaslahatan para hamba). Kemaslahatan adalah sesuatu yang mendorong kepada kebaikan (positif), dan menghindari kejelekan yang mendorong kepada kejelekan (negatif). ${ }^{14}$

Lebih lanjut soal tradisi, $\mathrm{R}$. Redfield seperti yang dikutip Bambang Pranowo mengatakan bahwa konsep tradisi itu dibagi dua yaitu tradisi besar (great tradition) dan tradisi kecil (little tradition).

Konsep ini menggambarkan bahwa dalam suatu peradaban manusia pasti terdapat dua macam tradisi yang dikategorikan sebagai great tradition dan little tradition. Little tradition adalah suatu tradisi dari mereka sendiri yang suka berpikir dan dengan sendirinya mencangkup jumlah orang yang relatif sedikit.

Sedangkan great tradition adalah suatu tradisi yang berasal dari mayoritas orang yang tidak pernah memikirkan secara mendalam pada tradisi yang telah mereka miliki. Tradisi yang ada pada filosof, ulama, dan kaum terpelajar adalah sebuah tradisi yang ditanamkan dengan penuh kesadaran, sementara tradisi dari kebanyakan orang adalah tradisi yang diterima dari dahulu dengan

14 M. Maftuhin ar-Raudli, Kaidah Fiqih Menjawab Problematika Sepanjang Zaman (Yogyakarta : Gava Media, 2015), 202. 
apa adanya (taken for granted) dan tidak pernah diteliti atau disaring pengembangannya. ${ }^{15}$

Sedangkan dalam konsep Islam yang demikian termasuk pada ruang lingkup penggunaannya, 'adât atau al'Urf yang dibagi menjadi dua bagian:

Al-'Urf 'âmm (kebiasaan umum), yaitu kebiasaan yang telah umum berlaku di mana-mana, hampir di seluruh penjuru dunia, tanpa memandang negara, bangsa, dan agama. Misalnya menganggukkan kepala tanda meyetujui dan menggelengkan kepala tanda menolak atau menidakkan, kalau ada orang berbuat kebalikan dari itu, maka dianggap aneh atau ganjil.

Al-'Urf khas (kebiasaan khusus), yaitu kebiasaan yang dilakukan sekelompok orang di tempat tertentu atau pada waktu tertentu; tidak berlaku di semua tempat dan di sembarang waktu. Misalnya : 'adât menarik garis keturunan melalui garis ibu atau perempuan (matrilineal) di Minangkabau dan melalui bapak (patrilineal) di kalangan suku Batak. ${ }^{16}$

Merumuskan teori tentang al-'Urf sebagaimana terurai diatas, maka akan dikaitkan dengan ta'aruf; yang dimaksud disini, sebuah proses perkenalan antara laki-laki dan perempuan untuk menuju perkawinan.

Sedangkan arti ta'aruf yakni silaturrahmi yang terjalin antara dua orang atau lebih untuk tujuan tertentu, bisa berupa persahabatan, persaudaraan, pernikahan dan lainlain. ${ }^{17}$

Ta'aruf (perkenalan) merupakan bagian dari Ukhuwah Islamiyah, dalam

15 Bambang Pranowo, Islam Factual Antara Tradisi Dan Relasi Kuasa (Yogyakarta: Adicita Karya Nusa, 1998), 3.

16 Amir Syarifuddin, Ushul Fiqh Jilid 2 (Jakarta : Kencana, 2011), 391.

17 Honey Miftahuljannah, A-Z Ta'aruf, Khitbah, Nikah, \& Talak Bagi Muslimah (Jakarta : PT Grasindo, 2014), 12.
Islam sangat dianjurkan untuk ummatnya saling ber-ta'aruf satu sama lain. Selanjutnya dalam perkembangannya, makna ta'aruf menurut al-'Urf masyarakat Indonesia dipersempit menjadi perkenalan antara laki-laki dan perempuan dalam pencarian pasangan hidup.

Proses ta'aruf atau perkenalan ini merupakan bagian yang memegang peranan yang sangat penting dari seluruh rangkaian proses pernikahan. Karna jika seseorang yang hendak membina rumah tangga, tentu harus mengenal dan mengetahui jati diri calon pasangan hidupnya tersebut.

Dengan demikian, ta'aruf atau perkenalan ini berfungsi sebagai proses penjajakan bagi calon pasangan suami istri untuk saling mengenal sebelum sampai pada proses khitbah (meminang). Dan disimpulkan bahwa ta'aruf merupakan jalan atau cara yang benar sesuai harkat kemanusiaan untuk mengenal calon pasangan hidup seseorang. ${ }^{18}$ Lalu sejauh mana batasan ta'aruf yang diperboleh dalam Islam?.

Islam membolehkan pertemuan antara laki-laki dan perempuan yang non-muhrim dalam batas-batas kewajaran yang dibolehkan secara syar'i. Ada kalanya pertemuan antara laki-laki dan perempuan menjadi sebuah tuntutan apabila bertujuan untuk kebaikan, seperti untuk tholabul 'ilmi, melakukan amal saleh, perjuangan, atau pekerjaan lain yang memerlukan antara laki-laki dan perempuan berada dalam satu ruang. ${ }^{19}$ Sedangkan ketika melakukan ta'aruf untuk kepentingan mengenal calon pasangan hidup, ada

18 Ilham Abdullah, Kado Buat Mempelai : Membentuk Keluarga Sakinah, Mawaddah Wa Rahmah (Yogyakarta : Absolut, 2003), 218.

19 Yusuf Al-Qaradhawi, Fatwa-fatwa Kontemporer Jilid 2 (Jakarta : Gema Insani, 1995), 392. 
beberapa hal yang diatur oleh islam diantaranya:

Menjaga pandangan dan hati dari perkara yang diharamkan yakni jenis maksiat yang disebut dengan zina mata (lahadhat). Bukan hanya sekedar pandangan mata, lahadhat adalah sumber itijah (orientasi) kemuliaan, juga sekaligus duta nafsu syahwat. Seseorang yang menjaga pandangan berarti ia menjaga kemaluan. ${ }^{20}$

Maksud dari menjaga hati dan pandangan adalah melihat lawan jenis dengan tanpa tatapan nafsu atau syahwat, karna ada dasarnya perbuatan maksiat dan kejahatan kebanyakan bermula dari pandangan mata. Itu sebabnya, Allah SWT terlebih dahulu memerintahkan untuk memejamkan mata sebelum menjaga kehormatan. ${ }^{21}$

Tidak melakukan khalawat berdua-duaan antara seorang laki-laki dan perempuan yang bukan mahram di tempat yang sepi atau tersembunyi, mengucapkan ucapan mesum pada perempuan yang bukan muhrim dan menghindari bersentuhan secara fisik

Adanya Mediator; yaitu seorang perantara bisa berasal dari kerabat maupun orang lain, pada masa sekarang mediator bisa juga berasal dari media social dan lain sebagainya. Selain itu, satu pihak dapat mengajukan sendiri atau mempertimbangkan calon perantara yang diajukan orangtuanya sepanjang sesuai dengan syarat-syarat penting selaku perantara. ${ }^{22}$

Jika selesai melakukan ta'aruf segera melakukan khitbah yakni seorang laki-laki meminta kepada seorang perempuan untuk menjadi istrinya, dengan cara-cara yang umum berlaku di

20 Rahman, Hudud dan Kewarisan (Jakarta : PT Raja Grafindo, 1996), 34.

21 Ibnul Qayyim al-Jauziyah, Jangan Dekati Zina (Jakarta : Pustaka Amani, 1995), 174.

22 Abdullah, Kado Buat Mempelai, 225.

23 Tihami, Fikih Munakahat, 24. tengah-tengah masyarakat ${ }^{23}$ dengan batasan-batasan tertentu sebagaimana sabda Rasulullah Saw.: "Dari Mughirah bin Syu'bah, sesungguhnya ia telah melamar seorang perempuan, lalu Rasulullah Saw berkata kepadanya : "melihatlah kepadanya karena yang demikian itu akan melanggengkan kasih sayang antara kalian berdua." 24

Jadi ta'aruf sebagai proses menuju kepernikahan adalah sebuah al-'Urfyang bisa dijadikan sebagai landasan atau sumber pembangunan hukum islam, para ulama' bersepakat bahwa hukum yang dibentuk berdasarkan pada al-'Urf bertahan selama al-'Urf berubah, maka kekuatan hukum itupun berubah. Dengan kata lain, bahwa ketetapan hukum islam yang dibangun berdasarkan pada al-'Urf tidak mempunyai ketetapan yang abadi.

\section{Praktek Ta'aruf dalam Adat "Gredoan" Masyarakat Using Banyuwangi}

Gredoan dalam bahasa using berarti saling menggoda (Nggridu = nggoda) atau dapat dipahami sebagai mekanisme budaya lokal dalam proses melakukan godaan terhadap lawan jenis. Namun Gredoan menjadi hal yang unik ketika menjadi sebuah tradisi yang dilakukan sebagai ajang pencarian jodoh atau perjodohan yaitu tepatnya di Desa Macan Putih Kecamatan Kabat Kabupaten Banyuwangi, Gredoan dilaksanakan setiap tahun bersamaan dengan peringatan perayaan Maulid Nabi Muhammad SAW yang selalu diadakan secara besar-besaran dan merupakan perayaan Maulid terbesar di wilayah kabupaten Banyuwangi. ${ }^{25}$

${ }^{24}$ Imam Tirmidzi, al-Jami' as-Şahih wa Huwa Sunan Tirmidzi : Abwâb an-Nikah (Beirut : Dar al-Fikr, 1983), 1093.

25 Dwi Pranoto, Membicarakan Seni Dan Sastra Banyuwangi (Bali : Pustaka Larasan, 2014), 77. 
Adapun proses Gredoan ini sudah dimulai sejak beberapa hari sebelum serangkaian acara peringatan perayaan Maulud Nabi Muhammad Saw. dilaksanakan. Dimana masyarakat using desa Macan Putih kecamatan Kabat Kabupaten Banyuwangi sudah mulai mempersiapkan berbagai hal yang dibutuhkan termasuk hidangan yang akan disuguhkan kepada para tamu. Karena itu, banyak keluarga yang sengaja mengundang sanak saudaranya dari dalam maupun luar desa terutama yang masih belum menikah untuk datang membantu. Sehingga pada momen-momen tersebut banyak muncul wajah-wajah baru yang kemudian dimanfaatkan oleh para muda-mudi sebagai ajang untuk mencari jodoh. ${ }^{26}$

Hal lain yang menarik yaitu bahwa masyarakat Using Banyuwangi percaya bahwa di bulan Maulid Nabi ini adalah bulan yang baik untuk mencari jodoh dan melakukan pernikahan bagi pasangan muda-mudi yang telah cukup umurnya. Sebab melakukan pernikahan bagi muda-mudi yang telah cukup umur dan sudah siap untuk menuju jenjang pernikahan juga dianggap telah mengikuti sunnah Nabi. ${ }^{27}$

Tidak dapat dipastikan kapan awal mula tradisi Gredoan mulai, dari hasil observasi di desa macan putih temuan yang didapat peniliti hanyalah sebuah perkiraan, sebagaimana penuturan Bapak Joko selaku tokoh masyarakat dan juga ketua POKDARWIS (Kelompok Sadar Wisata) di Desa Macan Putih Kecamatan Kabat Kabupaten Banyuwangi yang paham tentang tradisi Gredoan:

Mengenai kapan secara pasti munculnya itu belum ada yang dapat

26 Eko Budi Setianto, Bunga Rampai Ritual Adat Dan Tradisi Masyarakat Banyuwangi (Banyuwangi : Dinas Kebudayaan Dan Pariwisata Kabupaten Banyuwangi), 37.

27 Pranoto, Membicarakan Seni, 77. memastikan, namun ada memperkirakan sudah ada sejak tahun 1960, ada juga yang mengatakan kalau sebelum kemerdekaan itu sudah ada. dan seiring dengan perkembangan zaman dan majunya teknologi tradisi ini sudah berbeda dari dulu, baik dari segi prosesnya maupun alat komunikasinya. ${ }^{28}$

Dari penuturan bapak Joko diatas, kepastian tradisi Gredoan belum bisa dipastikan, diperkirakan sudah ada sejak tahun 1960 namun ada juga yang mengatakan sejak sebelum kemerdekaan Republik Indonesia tradisi ini sudah ada.

Pada awalnya, Gredoan bukanlah suatu tradisi yang hanya dilakukan bersamaan dengan peringatan maulid Nabi Muhammad saw, namun Gredoan ini biasa dilakukan kapan saja antara muda-mudi yang ingin mendapatkan pasangan dan dilakukan pada malam hari, sebagaimana diungkapkan oleh Bapak Safari salah satu sesepuh masyarakat di Desa Macan Putih Kecamatan Kabat Kabupaten Banyuwangi:

Zaman dulu itu Gredoan tidak hanya terjadi pada waktu maulidan, kapan saja bisa terjadi Gredoan. Waktu saya masih kecil itu, jika seseorang punya kenalan di dusun atau di lain desa, maka laki-lakinya datang kerumah sang perempuan, diluar sambil intip-intip dari balik gedhek sambil memberikan sodho. setelah itu terjadi pembicaraan antara keduanya jika perempuan merespon gudoan sang laki-laki maka akan berlanjut ke tahap khitbah dan selanjutnya ke jenjang pernikahan. ${ }^{29}$

Awalnya, proses Gredoan ini dilakukan para muda-mudi yang ingin mendapatkan jodoh dengan dibatasi

${ }^{28}$ Joko, Wawancara, Macan Putih, 15 Juni 2016.

29 Safari, wawancara, Macan Putih, 15 Juni 2016. 
dinding yang terbuat oleh bambu, menggunakan alat komunikasi berupa sodho / lidi. Keterangan ini diperkuat oleh bapak wahyudi salah satu warga Macan Putih Kecamatan kabat kabupaten Banyuwangi:

Iku bien awalê Gredoan, kan pas maulidan wong-wong iku benginê padha olah-olahan kanggo gawe panganan ring dina kesuk. Ring endi bain umah hang ana perawan mesti akeh diparani lancing hang arep Gredhoan. Mula iku umah hang sing duwe anak perawan biasane ditekani sanak keluarga hang magih perawan teka desa liya. Trus biyen kan umah e iku sek teko gedhek, dadi lancinglancingê hang arep gredo iku intipintip teko njobo, ambi nganggo sodho iku, di lebokakên nang bolonganê. ${ }^{30}$

(dulu Gredoan itu terjadi pada waktu maulid Nabi Muhammad SAW, pada malam hari kebanyakan orangorang sibuk membuat makanan untuk keesokan harinya. Di setiap rumah pasti ada anak perempuannya yang masih gadis yang kemudian banyak didatangi jejaka yang akang menggoda (gudho). Jika ada salah satu rumah yang tidak memiliki anak gadis, maka akan mendatangkan sanak saudaranya yang masih gadis dari desa lain. pada waktu dulu dinding rumahnya masih terbuat dari bambu, sehingga para jejaka mengintip dari luar dengan menggunakan lidi dan dimasukkan ke dalam lubang bambu tersebut).

Namun seiring berkembangnya zaman dan majunya tekhnologi, proses tradisi Gredoan telah banyak mengalami perubahan, diantaranya alat komunikasi untuk proses nggridu tidak lagi menggunakan sodho atau lidi dikarenakan bangunan rumah masyarakat sudah tidak ada yang terbuat dari gedhek melainkan sudah 2016.

${ }^{30}$ Yudi, wawancara, Macan Putih, 16 Juni

31 Sahilun A. Nasir, Tradisi Gredoan, 49. berupa gedung, sehingga sekarang para pelaku tradisi ini memilih dengan bertemu secara langsung atau menggunakan handphone. Selain itu, para jejaka dan gadis yang mengikuti tradisi sekarang lebih bebas dalam berinteraksi serta melakukan proses perkenalan atau dalam agama Islam lebih dikenal dengan istilah ta'aruf. Namun meskipun tradisi ini sudah banyak mengalami perubahan, masyarakat macan putih tetap melestarikan dan menjaga tradisi Gredoan ini. Bahkan mereka menganggap tradisi ini merupakan salah satu tradisi perjodohan yang bermartabat. Selanjutnya Gredoan menjadi sebuah tradisi yang dilaksanakan bersamaan dengan maulid Nabi Muhammad SAW. 31

Sakniki mlebet pun teng griyane, gawe nopo intip-intip,? langsung mertamu lan kenalan mawon, wong masak niku di tunggoni, trus kenalan, besoknya bisa di lanjut. waktu niku insun mertamu teng nggene (istri) trus kenal trus lanjut, langsung teng griyone ibu e. Nggeh orang tua pas waktu gredoan mboten melarang ada tamu yen medayoh. Di ajak ngobrol kaleh tiang sepah e kedap terus di tinggal nerusne masak soale kang sek repot masak pas dalu niko. Kulo nggeh perkenalan, lanjut menyambung, trus langsung njaluk, proses e mboten dangu. Pas niku nggeh seng diomongne nggeh tanglet-tanglet tentang larene pun. ${ }^{32}$

(kalau sekarang sudah langsung masuk ke rumahnya, buat apa mengintip? langsung bertamu dan kenalan. Ketika perempuannya masak didekati kemudian melakukan perkenalan, besoknya bisa dilanjut melamar ke rumah orang tuanya. Para orang tua kalau waktu Gredoan tidak

32 Abdul Halim, Wawancara, Macan Putih, 01 Mei 2016. 
melarang seandainya ada tamu. Di ajak berbincang-bincang dengan orang tuanya sebentar kemudian di tinggal meneruskan masak karena pada malam itu masih repot-repotnya. Sehingga saya perkenalan, lanjut menyambung kemudian melamar, prosesnya tidak lama. Ketika itu yang dibicarakan adalah segala sesuatu tentang pribadinya).

yo tepak pas Gredoan, kenalan telung ndino langsung dadi.Trus mari kenalan mrene maneh, trus neng wong tuwek, dadi wes, seng kari dowo. Biyen pas gudo iku, di delok KTP-ne, seng lancing ta grong, endi KTP ne. iki lancing, mulo kedigu pas muludan gudone, trus yo isun kekno, Trus sesok $e$ teko wong tuwekê, yo seneng, ketemune pas rame-rame iko, yo aran $e$ wes jodho. Entuk barokah e kanjeng Nabi. ${ }^{33}$

(ya kebetulan waktu gredoan itu, perkenalan selama 3 hari kemudian jadi (menikah). Setelah itu kembali lagi ke rumah langsung ke orang tua, jadi prosesnya tidak lama. Ketika itu proses Gredonya, di lihat KTP saya, dilihat masih gadis atau tidak, di minta KTP nya, kemudian ya saya kasihkan. Memang seperti itu waktu Gredo pas Maulid Nabi Muhammad SAW, kemudian besoknya ke orang tua, iya senang, bertemunya ketika acara rame-rame, ya seperti itu namanya jodoh, mendapatkan barokah dari Nabi Muhammad SAW).

Uraian diatas hasil wawancara dengan pelaku adat gredoan pada zaman sekarang, pada dasarnya tujuan dari tradisi Gredoan adalah sebagai sarana perjodohan bagi para muda-mudi yang tengah mencari pendamping hidup guna melakukan perkenalan sehingga bisa di lanjut ke jenjang pernikahan. Tradisi ini sudah turun temurun dan tidak sedikit juga masyarakat using yang mendapatkan jodoh dari tradisi
Gredoan, maka tradisi ini masih tetap dilestarikan hingga saat ini. Tradisi Gredoan juga merupakan salah satu aset adat budaya Banyuwangi yang berbeda dengan daerah yang lain.

Dalam prosesi gredoan ada beberapa tahapan yang harus dilakukan pemuda untuk meng-gredo sang perempuan, Pertama adalah nggridu, dalam proses ini sang pemuda mengincar pujaan hatinya jauh sebelum perayaan maulid nabi terjadi, dalam tradisi gredoan sang pemuda maupun pemudi tidak harus berasal dari suku using bisa jadi pemuda atau pemudi iti berasal dari daerah lain yang datang ataupun didatangkan oleh saudaranya yang bersuku using. Kedua, dódók sodho adalah prosesi selanjutnya yang dilakukan pada malam Maulid Nabi, prosesi ini sebenarnya masih masuk pada proses nggridu, menjadi langkah kedua karna proses ini merupakan awal puncak dari tradisi gredoan yang terjadi di bulan maulid. Dulu untuk meminang sang gadis, pemuda menggunakan media sodho atau lidi. Jika pinangan ditolak maka lidi tersebut dipatahkan oleh sang gadis demikian sebaliknya jika lamaran diterima maka lidi dikembalikan utuh kepada sang pemuda. Sekarang media dódók sodho sudah berubah tidak pakai lidi dikarenakan bangunan rumah masyarakat sudah tidak ada yang terbuat dari gedhek melainkan sudah berupa gedung, sehingga sekarang para pelaku tradisi ini memilih dengan bertemu secara langsung atau menggunakan handphone. Ketiga, Ngeleboni dimana sang pemuda datang berpamitan kepada orang tua gadis idamannya untuk mengenal dan meminang sang gadis, lalu orang tua sang gadis menanyakan asal-usul sang pemuda baik bebet, bobot dan bibitnya.

33 Muawanah, Wawancara, Macan Putih, 16 Juni 2016. 
Keempat, Mengumumkan bahwa sang gadis telah dipinang oleh sang pemuda, ini terjadi pada acara maulid dimushollah tempat acara mauled berlangsung. Kelima, lamaran yakni keluarga sang laki-laki datang untuk melamar sang perempuan. Keenam, Munggah Kawin adalah proses akad nikah, dalam proses ini selain dihadiri oleh keluarga kedua belah pihak juga datang para tetangga dan teman dari pihak perempuan dan laki-laki.

Dalam ajaran Islam, tradisi perjodohan dikenal dengan istilah ta'aruf, ta'aruf dalam Islam tentunya memiliki norma-norma yang harus dipatuhi yakni norma yang sesuai dengan syari'at Islam yakni adab-adab yang berhubungan dengan pertemuan dan pergaulan laki-laki dan perempuan ketika melakukan proses ta'aruf. Dalam hukum Islam ta'aruf merupakan 'Urf alShahih (kebiasaan yang dianggap sah) dengan kaidah fiqh al-'adât muhakammah (Adat kebiasaan dapat dijadikan (pertimbangan) hukum). Selanjutnya makalah ini akan membahas tradisi Gredoan sebagai ta'aruf lokalitas dengan mengintegrasikan hukum adat dengan 'urf dan kaidah fiqih yang dijadikan sandaran di dalam meneliti tradisi Gredoan jika dilihat dari sudut pandang hukum Islam.

\section{Integrasi Hukum Adat dan Hukum Islam dalam Fenomena Tradisi Gredoan}

Dalam pandangan hukum adat proses ta'aruf disebut pinangan, pada umumnya perbuatan pinangan bujang gadis untuk maksud menuju ke pernikahan adalah perbuatan yang tidak melanggar hukum adat. Tradisi Gredoan merupakan tradisi pinangan bagi masyarakat Using di Desa Macan Putih Kecamatan Kabat Kabupaten Banyuwangi yang tetap terjaga dan dilestarikan hingga saat ini, namun seiring dengan perkembangan zaman dan majunya teknologi tradisi ini banyak mengalami perubahan dalam pelaksanaannya. ${ }^{34}$

Adalah perubahan dalam proses pelaksanaan adat Gredoan dari dahulu hingga saat ini: Pertama, media komunikasi jika dulu komunikasi dalam adat Gredoan terhadap lawan jenis dengan menggunakan sodho atau lidi dan dibatasi oleh dinding yang terbuat dari bambu (gedhek), jika lamaran pemuda itu diterima maka sodho akan tetap utuh demikian sebaliknya jika lamaran itu ditolak maka sodho akan dipatahkan oleh sang perempuan. Namun saat ini para muda-mudi lebih memilih untuk bertemu secara langsung atau munggunakan handphone atau media sosial sebagai media komunikasinya. Kedua, Proses ta'aruf dalam adat Gredoan jika dulu dilaksanakan oleh para muda-mudi dengan cara mengintip gadis-gadis yang tengah membantu memasak di dapur dari balik dinding bambu selanjutnya memasukkan lidhi atau sodho melalui lubang dinding tersebut ke arah gadis yang dituju, namun saat ini para jejaka yang akan menggridu langsung bisa bertemu atau menuju rumah gadis yang ditujunya pada malam perayaan peringatan Maulid Nabi Muhammad SAW. Dalam hal ini, para orang tua serta masyarakat memberi kebebasan para muda-mudi untuk saling berkenalan karena memang sudah menjadi tradisi yang dilaksanakan tiap tahunnya yakni tradisi Gredoan. Dan tentunya harus memperhatikan batasan- batasan kewajaran yang sesuai dengan syari'at Islam.

Secara Hukum Adat dalam tradisi Gredoan berfungsi sebagai berikut:

Sebagai sarana perjodohan: masyarakat using banyuwangi berharap

34 Hilman, Hukum Perkawinan , 36. 
para anak serta family mereka yang masih single dapat menemukan jodohnya melalui tradisi Gredoan ini. Dan mereka percaya bahwa jodoh yang di dapat pada malam tradisi Gredoan akan barokah karena bersamaan dengan perayaan peringatan Maulid Nabi Muhammad Saw.

Menghindari pergaulan bebas: masyarakat using banyuwangi berharap dengan tetap dilestarikannya tradisi ini akan menjadi wadah untuk ajang pencarian jodoh, maka para orang tua serta masyarakat memberi kebebasan kepada anak-anak mereka untuk saling menggridu (menggoda) dengan pengawasan pantauan orang tua dan masyarakat. Sehinggga dalam proses pinangan itu akan terhindar dari perbuatan zina.

Sebagai sarana silaturrahmi: kepercayaan masyarakat using banyuwangi bahwa tradisi gredoan ini bisa dijadikan moment untuk berkumpul dengan sanak keluarga dan sekaligus akan menambah anggota keluarga.

Ditinjau dari segi hukum islam pelaksanaan tradisi Gredoan ini diperbolehkan, karna pada prinsipnya tradisi Gredoan adalah proses ta'aruf lokalitas sebagai ajang pencarian jodoh, yang bertujuan positif yakni sebagai sarana menuju pernikahan dan mempererat silaturrahmi. Dan pernikahan adalah sesuatu anjuran untuk menjaga seseorang dari perbuatan zina seperti disebutkan dalam QS. An- Nur (24):30 juga disebutkan dalam hadis:

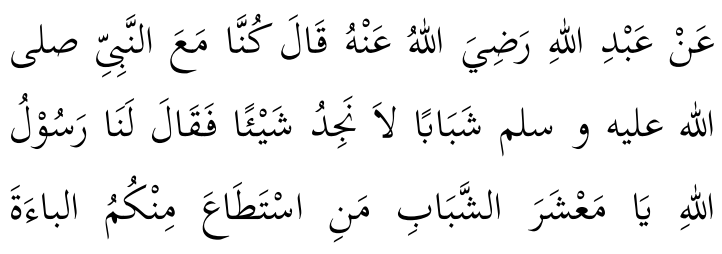

35 Bukhari, Shahih Imam Bukhari Juz 7-9,

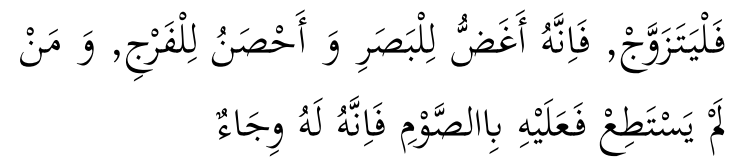

"Dari Abdullah r.a, ia berkata : "Kami pernah bersama-sama Nabi Saw. dan kami termasuk pemuda yang tidak punya apa-apa, lalu Rasulullah bersabda kepada kami : "Wahai para pemuda, barang siapa diantara kalian yang sanggup menikah, maka menikahlah. Karena sesungguhnya menikah itu memelihara pandangan mata dan memelihara kemaluan. Dan barang siapa yang belum sanggup menikah, maka hendaknya (ia) berpuasa karena sesungguhnya berpuasa itu merupakan benteng untuknya."35

Jika dikupas dari konsep mașlaḥah atau maqāṣid, Abū Hāmid al-Ghazālī memperkenalkan prinsip munāsabah atau kesesuaian sebagai salah satu cara untuk menemukan ratiolegis dalam nash. Menurutnya, alasan hukum atau 'illah dapat ditemukan dengan jalan yang sepenuhnya rasional dan logis. Dalam teori al-Ghazālī, prinsip munāsabah merupakan teknik pembacaan teks-teks Qur'an atau Sunnah secara seksama untuk menemukan "spirit hukum" yang melatari hukum-hukum Syarī'ah. Bila prinsip untuk mendatangkan kebaikan dan mencegah keburukan itu merupakan tujuan hukum-hukum Syarī‘ah, maka asas munāsabah harus sesuai dengan prinsip ini. Sebab, pada akhirnya tujuan Syarī‘ah adalah untuk mendatangkan kemaslahatan manusia di dunia maupun di akhirat. Di sinilah kemudian al-Ghazālī menyebutkan bahwa tujuan Syarīah adalah untuk melindungi kehidupan, harta, akal, agama, dan keturunan. Al-Ghazālī menyimpulkan kelima tujuan tersebut dari lima kejahatan utama dalam Islam yang mendapatkan hukuman tegas dari 
Syarī'ah (hudūd), antara lain pembunuhan, pencurian, minum khamr, murtad, dan zina. ${ }^{36}$

Al-Ghazālī juga menjelaskan bahwa tujuan Syarīcah itu beragam dan berlapis-lapis menurut kepentingannya, yang kemudian ia klasifikasi menurut taksonomi berikut:

1. darūrah, yaitu kebutuhan primer manusia yang hendak dilindungi oleh Syarī'ah yang mencakup kelima tujuan yang disebutkan di atas (alușūl al-khamsah).

2. hājiyah, kebutuhan sekunder manusia, yang dijelaskan oleh alGhazālī sebagai kebutuhan yang hanya diperlukan untuk menjaga ketenangan dan ketenteraman masyarakat.

3. tahsiniyah, tingkatan kebutuhan yang tujuannya hanyalah untuk meningkatkan dan memperluas (tahsīn, tausi'ah) penerapan tujuan Syarī‘ah. ${ }^{37}$

Al-Syāṭibī menjelaskan bahwa tujuan asal Allah dalam menciptakan hukum adalah untuk melindungi kepentingan manusia, yang duniawi maupun yang ukhrawi, dalam ketiga kategori darūriyyāt, hājiyyāt, dan tahsinniyyāt seperti yang dikemukakan oleh al-Ghazālī sebelumnya. Menurutnya, "Syarī'ah diciptakan untuk [menciptakan] kemaslahatan umat manusian" (al-Syarī'atu wudi'at limașālih al-ibād). ${ }^{38}$ Sementara AlGhazālī menetapkan beberapa syarat agar maslahah dapat dijadikan sebagai dasar hukum. Adapun syaratnya adalah sebagai berikut pertama, Kemaslahatan itu bentuk dari kategeori darūriyyāt.

${ }^{36}$ Al-Ghazālī, Syifā’ al-Ghalīl fì al-Syabah wa'l-Mukhīl wa Masālik al-Ta'î̀l, diedit oleh Hamd al-Kabīsī (Baghdad: Matba'at al-Irsyād, 1971), hlm. 142-266. Lihat juga ikhtisarnya dalam Wael B. Hallaq, A History of Islamic Legal Theories: An Introduction to Sunnī Ușūl al-Fiqh (Cambridge: Cambridge University Press, 1997), hlm. 86-90.
Artinya bahwa untuk menetapkan suatu kemaslahatan, tingkat keperluan harus diperhatikan apakah akan sampai mengancam eksistensi lima unsur pokok maslahat atau belum sampai batas tersebut.

Kedua, Kemaslahatan itu besifat qat'i Artinya yang dimaksud dengan maslahat tersebut benar-benar diyakini sebagai maslahat, tidak didasarkan pada dugaan (zhan) semata.

Ketiga, Kemaslahatan itu bersifat kulli artinya kemaslahatan itu berlaku secara umum atau kolektif tidak bersifat individual. Kalaupun harus bersifat individual maslahat harus sesuai maqāșid al-Syarī̄ah. ${ }^{39}$

Istilah maqāșid al-Sharī‘ah, adat gredoan sudah sesuai dengan maqāṣid al- Syarīah yang didalamnya adanya kemaslahatan, dalam katagori ini Maslahah Mursalah yakni suatu kemaslahatan yang tidak ditetapkan oleh syara' dan tidak pula ada dalil yang memerintahkan untuk memperhatikannya maupun mengabaikannya. Bukan Maslahah Mu'tabarah; karena tidak ada nash yang menganjurkannya. Dan bukan pula maslahah mulghah karena tidak ada nash yang bertentangan dengan tradisi tersebut, alasan lainnya memperbolehkan adalah karena tradisi Gredoan adalah tradisi yang sudah turun temurun yang di lakukan oleh masyarakat using Banyuwangi.

Selanjutnya tulisan ini akan mengupas tradisi Gredoan sebagai proses ta'aruf menuju keperkawinan jika ditinjau dari segi al-'Urf. Maka peneliti lebih melihat tradisi Gredoan

37 Al-Ghazālī, Syifä’’ al-Ghalīl, hlm. 161.

38 Al-Syāțibī, Al-Muwāfaqāt fĩ Ușūl alSyarī‘ah, diedit oleh Muhammad 'Abd Allāh Darrāz, 4 jilid (Kairo: al-Maktabah al-Tijāriyyah al-Kubrā, t.t.), II: 67.

${ }^{39}$ Abū Hāmid Al-Ghazālī, Al-Mustașfā min 'Ilm al-Ușūl. (Beirut: Dār al-Fikr, t.t.), 4 
condong dari segi keabsahannya, pertama kali akan dikaji al-'Urf secara historis Rasulullah sebagai legislator Islam diwilayah mekkah dan madinah beliau banyak mengadopsi al-Urf setempat. Sebagian al-'Urf tersebut ditetapkannya sebagai wahyu al-Qur'an dan Hadith ${ }^{40}$ argumentasi Rasulullah dalam menyetujui al-'Urf karna al-'Urf mampu menyediakan pemecahan yang diperkirakan bisa memberi kepuasan kebutuhan masyarakat tertentu. Namun tidak semua tradisi arab menjadi bagian dari syari'ah islam, beberapa diantaranya direvisi dan dimodifikasi ${ }^{41}$ dan sebagian lain dibatalkan berdasarkan wahyu dari Allah Swt. Seperti persoalan riba dan cara memperlakukan perempuan dalam hal pernikahan dan kewarisan. Dan dalam bangunan hukum Islam dari zaman Rasulullah Saw. hingga hari ini, tidak bisa dipisah dari factor al-'Urf meskipun al-'Urf masih menjadi perdebatan dikalangan fuqaha tapi adanya tidak nisa dihindari karna belum adanya kesepakatan tunggal tentang al-'Urf. Karna sebagian fuqaha menyadari bahwa al-'Urf merupakan salah satu topik yang kontroversial dalam perdebatan islam.

Gredoan sebagai al-'Urf dalam proses ta'aruf menuju pernikahan bisa menjadi bagian dari syari'ah islam, jika ada penyimpangan yang terjadi dalam tradisi Gredoan yang dilakukan oleh personal individu, yaitu melalui alat komunikasi yang sudah canggih para pemuda melakukan nggridu kepada lawan jenis melalui media social sebelum Gredoan dan ketika tiba pada

40 Muhammad el Awa, The Place of Custom ('Urf) in Islamic Legal Theory, 177-178

41 Ratno Lukito, Islamic Law and Adat Encounter; the experience of Indonesia (jakarta: Logos Wacana Ilmu,2001), 7

42 Muhammad Sidqi Ibn Ahmad al-Burnu, al- Wajiz Fi idhah Qawaid al-Fiqhal-Kulliyah, (Bairut: Muassasah al-Risalah, 1983), 157 puncak tradisi Gredoan mereka memilih bertemu diluar rumah dari pada datang kerumah sang perempuan, hal ini sebenarnya menurut hukum Islam tidak diperbolehkan. Alasan tidak diperbolehkannya karena melihat dari proses pelaksanannya sendiri sudah tidak sesuai dengan konsep ta'aruf yang sesuai dengan syari'at Islam. Sedangkan ta'aruf yang menyimpang dari hukum islam masuk pada kategori al-'Urf alFasid yakni tradisi yang berlawanan dengan dalil syari'ah atau menghalalkan keharaman maupun membatalkan kewajiban ${ }^{42}$ jelas tidak boleh dipelihara, karena pemeliharaan tradisi ini akan mengakibatkan kerusakan.

Prof. Dr. K.H. Sulaiman Abdullah sebagaimana yang dikutip ashshubli mengatakan bahwa menurut syara sesuatu yang dilakukan oleh orang banyak dan mengandung maslahat namun tidak bertentangan dengan ajaran agama maka hal tersebut boleh dilakukan dan dilestarikan. Karna pada prinsipnya agama Islam tidak memberantas tradisi, selama tradisi tersebut tidak merusak aqidah umat. Agama Islam menegaskan bahwa jika suatu tradisi mengarah pada perusakan akidah maka harus ditinggalkan ${ }^{43}$.

Untuk mencegah kemudharatan atau hal-hal yang tidak diinginkan dalam tradisi Gredoan tersebut, perlu adanya pembenahan dan pelurusan secara adat dilingkungan masyarakat. Agar tradisi yang sudah turun-temurun dan menjadi salah satu aset adat budaya masyarakat using banyuwangi ini tidak lagi bertentangan dengan syari'ah Islam. Di dalam kajian Islam sendiri apabila

43 Muhammad ashsubli, Ritual Budaya Mandi Safar di Desa Tanjung Punak Pulau Rupat kabupaten Bengkalis Provinsi Riau, Aqlam: Jurnal of Islam and Plurality, Vol.3 No.1 Juni 2018, 85- 99 
terdapat suatu permasalahan 'adat / tradisi atau dalam hukum Islam dikenal dengan istilah al-'urf ini adalah dengan menggunakan kaidah fiqih

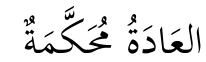

"Adat kebiasaan dapat dijadikan (pertimbangan) hukum"

Sebagaimana yang telah dipaparkan diatas bahwa tradisi / 'urf yang dapat dijadikan landasan hukum adalah 'urf yang șahîh, yang telah memenuhi beberapa persyaratan yaitu :

1. 'Adat atau 'urf sudah ada sebelum munculnya kasus yang akan ditetapkan hukumnya dan diterima akal sehat

2. 'Adat atau 'urf itu berlaku umum dan merata di kalangan orang-orang yang berada di lingkungan 'adat itu atau di kalangan sebagian besar warganya.

3. 'urf tidak bertentangan dengan yang diungkapkan secara jelas dalam suatu akad (transaksi)

4. tidak bertentangan dan melalaikan nash ${ }^{44}$

Penyelesaian hukum secara publik harus menggali dari nilai- nilai hukum yang ada dimasyarakat, maka dari itu pentingnya menggali nilai-nilai local dalam masyarakat baik dari hukum adat maupun hukum agama. Berangkat dari landasan inilah Maksud dari Integrasi hukum Adat dan hukum Islam dalam makalah ini adalah upaya meleburnya Hukum Adat dengan Hukum Islam dalam melihat dan mencermati konsep ta'aruf dalam tradisi gredoan.

Qoidah ushuliyah menyebutkan "al 'adat al Muhakkamah" bahwa adat bisa menjadi sebuah hukum, merupakan cela hukum yang dapat mengintegrasikan antara hukum adat dengan hukum islam itu sendiri. Dalam tanda kutip, jika adat yang baik dan adat tersebut memiliki maslahat sebagai dasar peletakan Adat istiadat tersebut, maka adat tersebut merupakan adat yang baik dan patut di anggap atau dijadikan hukum.

Praktek Gredoan dapat kita lihat pada sisi positifnya, tradisi ini tidaklah menyimpang dari tujuan hukum islam itu sendiri yakni hifdz al-dīn, hifdz alnafs, hifdz al-aql, hifdz al-mal, hifd alnasl. Selain di perkuat dengan konsep tujuan Maqasid as- Syari'ah, adat Gredoan dibolehkan karena ada integrasi antara hukum adat dan hukum Islam yang di landasi dengan Qaidah "al'adat al-Muhakkamah".

\section{Penutup}

Islam memiliki etika dalam pergaulan dan mengadakan perkenalan antara pria dan wanita sebelum menuju jenjang pernikahan. Dalam proses perkenalan yang sesuai dengan syari'ah dalam masyarakat kita dipopulerkan dengan istilah ta'aruf.

Tradisi gredoan yang disama artikan sebagai ta'aruf, yakni; sebagai proses untuk dapat mengenal kepribadian, latar belakang keluarga, maupun agama kedua belah pihak yang bertujuan untuk mencari pasangan hidup.

Jadi ta'aruf di tradisi gredoan sebagai proses menuju kepernikahan adalah sebuah al-'Urf yang bisa dijadikan sebagai landasan atau sumber pembangunan hukum islam, para ulama' bersepakat bahwa hukum yang dibentuk berdasarkan pada al-'Urf bertahan selama al-'Urf berubah, maka kekuatan hukum itupun berubah. Dengan kata lain, bahwa ketetapan hukum islam yang dibangun berdasarkan pada al-'Urf tidak mempunyai ketetapan yang abadi.

Gredoan sebagai tradisi ajang pencari jodoh yang terjadi turun temurun dikalangan masyarakat using di Desa Macan Putih Kecamatan Kabat Kabupaten Banyuwangi, dilaksanakan

${ }^{44}$ Nasrun Haroen, Ushul Fiqh, 144 
setiap satu tahun sekali bersamaan dengan peringatan Maulid Nabi Muhammad saw. bisa dijadikan bagian dari syari'ah Islam karena mendapatkan legitimasi dengan adanya tinjaun Maqasid Syari'ah berupa menimbulkan kemaslahatan. yang di landasi dengan kaidah "al-'âdat al-Muhakkamah".

\section{DAFTAR PUSTAKA}

Abdullah,Ilham. 2003. Kado Buat Mempelai: Membentuk Keluarga Sakinah, Mawaddah Wa Rahmah. Yogyakarta : Absolut.

el Awa, Muhammad. The Place OfCustom ('Urf) in Islamic Legal Theory, 177178

Budi Setianto, Eko. Bunga Rampai Ritual Adat Dan Tradisi Masyarakat Banyuwangi . Banyuwangi : Dinas Kebudayaan Dan Pariwisata Kabupaten Banyuwangi.

Bukhori. 1349. Shahih Bukhori. Mesir : Kementrian Abdurrahman Affandi Muhammad al-Azhar.

Effendi, Satria. Ushul Fiqh. 2009.Jakarta : Kencana.

Al-Ghazālī, Abū Hāmid . tt. Al-Mustașfā min 'Ilm al-Ușūl. Beirut: Dār alFikr.

1971. Syifä’ al-Ghalīl fì alSyabah wa'l-Mukhīl wa Masālik alTa'līl, diedit oleh Hamd al-Kabīsī. Baghdad: Mațba'at al-Irsyād.

Hadikususma, Hilman. 1999. Hukum Perkawinan Adat. Bandung: Citra Aditya Bakti.

Hakim, Rahmat. 2000. Hukum Perkawinan Islam. Bandung : CV Pustaka Setia.
Hallaq, Wael B. 1997. A History of Islamic Legal Theories: An Introduction to Sunnī Ușūl al-Fiqh. Cambridge: Cambridge University Press.

Karim Zaidan, karim. Tt. al- Wajiz Fi Ușūl al-Fiqh. kairo: Dhar al-Fikr.

Lukito, Retno. Islamic Law and Adat Encounter; the experience of Indonesia . Jakarta: Logos Wacana Ilmu.

Maftuhin ar-Raudli, M. 2015. Kaidah Fiqih Menjawab Problematika Sepanjang Zaman . Yogyakarta : Gava Media.

Miftahul jannah, Haney. 2014. A-Z Ta'aruf, Khitbah, Nikah, \& Talak Bagi Muslimah .Jakarta : PT Grasindo.

Muhammad Sidqi Ibn Ahmad al-Burnu. 1983. al- Wajiz Fi idhah Qawaid al-Fiqhal-Kulliyah. Bairut: Muassasah al-Risalah.

Nurvatisna, Sheila. "Tradisi Gredoan", http://osingkertajasa.wordpress. com (15 Desember 2015).

Pranoto,Dwi. 2014. Membicarakan Seni Dan Sastra Banyuwangi.Bali : Pustaka Larasan.

Pranowo, Bambang. 1998. Islam Factual Antara Tradisi Dan Relasi Kuasa .Yogyakarta: Adicita Karya Nusa.

Al-Qaradhawi,Yusuf. 1995. Fatwa-fatwa Kontemporer Jilid 2.Jakarta : Gema Insani.

Qayyim al-Jauziyah, Ibnu. 1995. Jangan Dekati Zina.Jakarta : Pustaka Amani.

Ashsubli, Muhammad. 2018. Ritual Budaya Mandi Safar di Desa Tanjung Punak Pulau Rupat kabupaten Bengkalis Provinsi Riau. Aqlam: Jurnal of Islama and Plurality. Vol.3 No.1, 85- 99 
Syafe'i, Rahcmat. 2007. Ilmu Ushul Fiqh. Bandung : CV Pustaka Setia.

Syarifuddin,Amir. 2011. Ushul Fiqh Jilid 2 . Jakarta : Kencana.

Al-Syāțibī. Tt. Al-Muwāfaqāt fì Ușūl alSyarī‘ah, diedit oleh Muhammad 'Abd Allāh Darrāz, 4 jilid .Kairo: alMaktabah al-Tijāriyyah al-Kubrā.

Pranowo, Bambang. 1998. Islam Factual Antara Tradisi Dan Relasi Kuasa .Yogyakarta: Adicita Karya Nusa.

Rahman.1996. Hudud dan Kewarisan.Jakarta : PT Raja Grafindo.

Tihami.2010. Fikih Munakahat.Jakarta : PT RajaGrafindo Persada.

Tirmidzi, Imam. 1983. al-Jami' as-Sahih wa Huwa Sunan Tirmidzi : Abwab an-Nikah .Beirut : Dar al-Fikr.

Wahhab Khallaf, Abdul. Tt. IIm Ușūl Fiqh. Qahirah: Dar al-Qalam. 